\title{
TERTIB JENIS, HIERARKI, DAN MATERI MUATAN PERATURAN PERUNDANG-UNDANGAN: PERMASALAHAN DAN SOLUSINYA
}

\author{
Bayu Dwi Anggono \\ Fakultas Hukum Universitas Jember \\ Jalan Kalimantan 37 Kampus Tegal Boto Jember \\ bayu fhunej@yahoo.co.id
}

\begin{abstract}
There are 2 rules of legislation that is the basic rules of legislation and orderly formulation of legislation. The practice of the Indonesian legislation system following the enactment of Law 12/2011 points to the issue of the basic rules of legislation that are less controlled by the types of regulations that can be classified as legislation, not all types of laws and regulations are clearly located in the hierarchy and the extent of the content and similarity of material content between laws and regulations. Efforts to realize the orderliness of legislation can be done by issuing unregistered types of regulatory bodies as legislation, putting each type of legislation in the hierarchy, and tightening of a content material that can be regulated by legislation, as well as making a distinction clearly the content of each type of legislation.
\end{abstract}

Keyword: Orderly Type; Hierarchy; Material Content.

\begin{abstract}
Abstrak
Terdapat 2 tertib peraturan perundang-undangan yaitu tertib dasar peraturan perundangundangan dan tertib pembentukan peraturan perundang-undangan. Praktik sistem perundangundangan Indonesia pasca diberlakukannya UU 12/2011 menunjukkan permasalahan pada tertib dasar perundang-undangan yaitu kurang terkontrolnya jenis peraturan yang dapat digolongkan sebagai peraturan perundang-undangan, tidak semua jenis peraturan perundang-undangan jelas letaknya dalam hierarki dan terlalu luasnya materi muatan serta kesamaan materi muatan antar peraturan perundang-undangan. Upaya mewujudkan tertib peraturan perundang-undangan dapat dilakukan dengan mengeluarkan jenis peraturan lembaga yang tidak berkategori sebagai peraturan perundang-undangan, meletakkan setiap jenis peraturan perundang-undangan dalam hierarki, dan pengetatan suatu materi muatan yang dapat diatur dengan peraturan perundangundangan, serta melakukan pembedaan secara jelas materi muatan tiap jenis peraturan perundang-undangan.
\end{abstract}

Kata kunci: Tertib Jenis; Hierarki; dan Materi Muatan.

\section{A. Pendahuluan}

Untuk memastikan agar peraturan perundang-undangan dapat mendukung tegaknya prinsip negara hukum maka setidaknya diperlukan 2 tertib yaitu tertib dasar peraturan perundang-undangan dan tertib pembentukan peraturan perundangundangan. Tertib dasar peraturan perundangundangan terkait dengan asas, jenis, hierarki dan materi muatan, sementara tertib pembentukan peraturan perundang-undangan terkait dengan perencanaan, penyusunan, pembahasan, pengesahan atau penetapan dan
pengundangan(Natabaya, 2006).

Undang-Undang Nomor 12 Tahun 2011 tentang Pembentukan Peraturan perundang-undangan (UU 12/2011) di bagian penjelasan umum menyatakan pentingnya 2 tertib tersebut. Pengakuan tersebut terwujud dengan UU 12/2011 memuat materi-materi pokok tentang asas; jenis, hierarki, dan materi muatan peraturan perundang-undangan; perencanaan; penyusunan; teknik penyusunan; pembahasan dan pengesahan/penetapan rancangan peraturan perundang-undangan. 
Praktik sistem perundang-undangan Indonesia pasca diberlakukannya UU 12/2011 menunjukkan bahwa tertib dasar peraturan perundang-undangan dan tertib pembentukannya masih menghadapi permasalahan. Dalam The Worldwide Governance Indicators (WGI) project tahun 2016 yang disusun oleh Bank Dunia untuk dimensi kualitas regulasi (regulatory quality) Indonesia berada di peringkat 93 dari 193 negara. Dari skala skor -2.5 (lemah) sampai 2.5 (kuat) Indonesia mendapatkan skor -0.12 (World Bank, 2016). Indikator regulatory quality dalam WGI adalah menggambarkan mengenai sejauh mana penghormatan warga negara dan negara terhadap regulasi yang mengatur interaksi ekonomi dan sosial di antara mereka (Kaufmann, Daniel. Kraay, Aart \& Mastruzzi, n.d.).

Secara garis besar problematika tertib dasar peraturan perundang-undangan disebabkan oleh banyak faktor, pertama, kurang terkontrolnya jenis peraturan yang dapat digolongkan sebagai peraturan perundang-undangan. Kedua, materi muatan peraturan perundang-undangan yang tidak dapat ditetapkan secara pasti. Ketiga, ketidakjelasan hierarki peraturan perundangundangan sehingga menyulitkan dalam pengujiannya(Anggono, 2014)

Adapun permasalahan tertib pembentukan peraturan perundang-undangan adalah penyusunan dan realisasi program perencanaan pembentukan peraturan perundang-undangan yang kurang rasional, permasalahan dalam proses harmonisasi rancangan peraturan perundang- undangan, minimnya ruang partisipasi publik dalam pembahasan, dan belum dilembagakannya evaluasi peraturan perundang-undangan (Anggono, 2014). Secara khusus akibat belum tertib nya pembentukan ini berakibat tingginya peraturan perundang-undangan yang dibatalkan oleh pengadilan.

Sejak putusan Mahkamah Konstitusi pertama tahun 2003, sampai tanggal 31 Desember 2017 tercatat telah ada 1134 perkara pengujian UU yang masuk ke MK dengan jumah putusan terunggah sebanyak 1007 putusan. Komposisi putusan MK adalah permohonan dikabulkan sebanyak 222 perkara $(20.40 \%)$; ditolak 379 perkara (34.83 $\%$ ); tidak dapat diterima 355 perkara
(32.63\%); penarikan permohonan 100 perkara (9.19\%); gugur 22 perkara $(2.02 \%)$, dan bukan kewenangan MK 10 perkara $(0.92 \%)$ (Laporan LeIP, 2018).

Mengingat luasnya 1 ingkup pembahasan mengenai 2 jenis tertib tersebut, maka tulisan ini hanya akan membahas upaya mewujudkan tertib dasar peraturan perundang-undangan, adapun mengenai tertib pembentukan peraturan perundangundangan akan dibahas di tulisan lainnya. Mewujudkan tertib peraturan perundangundangan yang dimaksud adalah penataan ulang terhadap jenis, hierarki dan materi muatan peraturan perundang-undangan.

\section{B. Pembahasan \\ 1. Jenis Peraturan Perundang- undangan}

Sebagai konsekuensi dari pilihan negara hukum maka segala aspek kehidupan dalam bidang kemasyarakatan dan pemerintahan Indonesia harus senantiasa berdasarkan atas hukum yang salah satunya terwujud dalam berbagai peraturan negara. Peraturan negara (staatsregelings) menurut M.Solly Lubis adalah peraturan-peraturan tertulis yang diterbitkan oleh instansi resmi, baik dalam pengertian lembaga maupun dalam pengertian pejabat tertentu meliputi Undang-Undang, Peraturan Pemerintah Pengganti Undang-Undang, Peraturan pemerintah, Peraturan Daerah, instruksi, surat edaran, pengumuman, surat keputusan, dan lain-lain(Lubis, 1977).

Peraturan negara (staatsregelings) atau keputusan dalam arti luas (besluiten) dapat dibagi dalam 3 (tiga) kelompok yakni wettelijk regeling (peraturan perundangundangan), beleidsregels (peraturan kebijaksanaan), dan beschikking (penetapan). Termasuk dalam wettelijk regeling (peraturan perundang-undangan), seperti UUD, Undang-Undang, Peraturan Pemerintah Pengganti Undang-Undang, Peraturan Pemerintah, Peraturan Presiden, Peraturan Daerah, Peraturan Desa, dan lain-lain. Termasuk beleidsregels (peraturan kebijaksanaan), seperti instruksi, surat edaran, pengumuman dan lain-lain. Sementara termasuk beschikking (penetapan), seperti surat keputusan dan lainlain(Astawa, I Gde Pantja \& Na,a, 2008) 
Terdapat 4 sifat atau ciri dari suatu peraturan perundang-undangan (wettelijk regeling) yaitu, pertama, berupa keputusan tertulis, jadi mempunyai bentuk atau format tertentu. Kedua, dibentuk, ditetapkan, dan dikeluarkan oleh pejabat yang berwenang, baik di tingkat pusat maupun tingkat daerah berdasarkan atribusi maupun delegasi. Ketiga, berisi aturan pola tingkah laku, dengan demikian peraturan perundangundangan bersifat mengatur (regulerend), tidak bersifat sekali jalan (einmahlig). Keempat, mengikat secara umum (karena ditujukan kepada umum), artinya tidak ditujukan kepada seseorang atau individu tertentu/tidak bersifat individual (Ranggawidjaja, 1998).

Mengenai apa saja jenis peraturan perundang-undangan di Indonesia saat ini, maka rujukannya adalah Pasal 7 ayat (1) dan Pasal 8 ayat (1) UU 12/2011. Pasal 7 ayat (1) mengatur jenis peraturan perundangundangan adalah: a. Undang-Undang Dasar Negara Republik Indonesia Tahun 1945; b. Ketetapan Majelis Permusyawaratan Rakyat; c. Undang-Undang/Peraturan Pemerintah Pengganti Undang-Undang; d. Peraturan Pemerintah; e. Peraturan Presiden; f. Peraturan Daerah Provinsi; dan g. Peraturan Daerah Kabupaten/Kota.

Selain jenis peraturan perundangundangan yang diakui oleh Pasal 7 ayat (1), Pasal 8 ayat (1) juga mengatur Jenis Peraturan Perundang-undangan lainnya yang mencakup peraturan yang ditetapkan oleh Majelis Permusyawaratan Rakyat, Dewan Perwakilan Rakyat, Dewan Perwakilan Daerah, Mahkamah Agung, Mahkamah Konstitusi, Badan Pemeriksa Keuangan, Komisi Yudisial, Bank Indonesia, Menteri, badan, lembaga, atau komisi yang setingkat yang dibentuk dengan Undang-Undang atau Pemerintah atas perintah Undang-Undang, Dewan Perwakilan Rakyat Daerah Provinsi, Gubernur, Dewan Perwakilan Rakyat Daerah Kabupaten/Kota, Bupati/Walikota, Kepala Desa atau yang setingkat. Untuk dapat diakui keberadaannya dan mempunyai kekuatan hukum mengikat sebagai peraturan perundang-undangan maka Pasal 8 ayat (2) mensyaratkan peraturan perundangundangan sebagaimana dimaksud pada Pasal 8 ayat (1) diperintahkan oleh peraturan perundang-undangan yang lebih tinggi atau dibentuk berdasarkan kewenangan.

Terhadap pengaturan jenis peraturan perundang-undangan oleh Pasal 7 ayat (1) dan Pasal 8 ayat (1) dan ayat (2) terdapat beberapa permasalahan yang perlu mendapat perhatian. Keberadaan Pasal 8 ayat (1) telah menimbulkan permasalahan mengingat sesuai dengan sifat atau ciri peraturan perundang-undangan maka tidak semua jenis peraturan yang dibentuk oleh lembaga negara atau pejabat dapat dikategorikan sebagai peraturan perundang-undangan. Keberadaan Pasal 8 ayat (1) telah memberikan pemahaman baru bahwa semua peraturan seperti peraturan MPR, peraturan DPR, peraturan DPD, peraturan MA, peraturan MK masuk kategori peraturan perundangundangan sepanjang diperintahkan oleh peraturan perundang-undangan yang lebih tinggi atau dibentuk berdasarkan kewenangan. Padahal tidak semua lembaga tersebut dapat membentuk peraturan yang mengikat ke luar.

Sebagai contohnya adalah Peraturan MA dan Peraturan MK, dimana tidak seharusnya badan peradilan diberikan kewenangan untuk membentuk peraturan perundang-undangan. Sudah menjadi pemahaman bahwa dalam sistem negara yang berdasarkan hukum syarat yang pertama adalah pengadilan itu tidak seharusnya membuat peraturan yang bersifat umum dan mengatur keluar.

Keberadaan Peraturan MA dan Peraturan MK seharusnya tidak boleh bersifat perundang-undangan artinya tidak boleh mengikat keluar. Menurut Alexander Hamilton dalam Federalist Paper 78 kekuasaan kehakiman adalah kekuasaan yang paling "netral" dalam pengertian bahwa sesuai dengan sifat dan fungsinya kekuasaan yudikatif berbeda dengan kekuasaan eksekutif yang memegang kekuasaan pelaksana negara dan cabang legislatif yang memegang kekuasaan penggunaan keuangan negara dan menentukan Undang-Undang yang berlaku, maka kekuasaan yudikatif tidak memegang salah satu pun dari kekuasaan tersebut(Thalib, 2006).

Berdasarkan sifat kekuasaan yudikatif yang netral, maka hakim diberikan kekuasaan tidak hanya untuk menangani kasus peradilan 
umum pidana atau perdata, melainkan lebih luas dari itu, juga menjadi hakim untuk keadilan konstitusi. Bentuk dari menjadi hakim keadilan konstitusi dilakukan dengan meletakkan kewenangan badan kehakiman untuk melakukan uji materiil peraturan perundang-undangan yang diberlakukan apakah sesuai dengan konstitusi atau tidak.

Di Indonesia kekuasaan tersebut diletakkan di tangan Mahkamah Konstitusi dan Mahkamah Agung. Mahkamah Konstitusi sesuai dengan Pasal 24C ayat (1) UUD 1945 memiliki kewenangan menguji UU terhadap UUD. Sementara MA sesuai Pasal 24A ayat (1) UUD 1945 berwenang menguji peraturan perundang-undangan di bawah undang-undang terhadap undangundang.

Mengingat konstruksi sifat dasar kekuasaan yudikatif dan diberikannya kewenangan menguji konstitusionalitas peraturan perundang-undangan kepada badan yudikatif yaitu MK dan MA, maka keputusan menggolongkan Peraturan MK dan Peraturan MA sebagai jenis peraturan perundangundangan akan menimbulkan potensi kesewenang-wenangan dan melanggar prinsip supremasi konstitusi mengingat peraturan tersebut tidak dapat menjadi objek pengujian di pengadilan. Tentu tidak mungkin MA akan mengadili permohonan judicial review pengujian Peraturan MA apabila diajukan oleh warga negara mengingat MA pula yang membentuk Peraturan MA tersebut.

Selain MK dan MA maka terdapat beberapa lembaga negara yang dari segi fungsi dan kewenangan yang diberikan oleh UUD 1945 sebenarnya tidak memiliki kewenangan untuk membentuk peraturan perundang-undangan yang bersifat umum dan berlaku keluar. Diantara lembaga negara yang dimaksud tersebut adalah MPR, DPR (sebatas membentuk UU dengan persetujuan Presiden), DPD (hanya sebatas mengajukan rancangan undang-undang kepada DPR), dan BPK yang hanya berwenang membentuk peraturan yang mengikat ke dalam (Soeprapto, 2007).

Dari cabang-cabang kekuasaan negara yaitu legislatif, eksekutif, yudikatif pada dasarnya yang diberikan kuasa mengatur melalui pembentukan peraturan perundangundangan adalah cabang kekuasaan legislatif dan eksekutif. Lembaga legislatif merupakan organ utama pembentuk produk legislatif sementara lembaga eksekutif bertindak sebagai lembaga sekunder dalam pembentukan peraturan perundang-undangan (utamanya peraturan di bawah undangundang). Menurut A Hamid S. Attamimi kekuasaan mengatur oleh lembaga legislatif dinamakan dengan pouvoir legislatif, sedangkan kekuasaan mengatur yang dimiliki oleh lembaga eksekutif untuk menjalankan atau mengatur bekerjanya UU disebut dengan pouvoir reglementaire (Latif, 2014).

Meskipun badan-badan diluar lembaga legislatif memiliki wewenang untuk membentuk peraturan perundang-udangan namun pada dasarnya tidak semua jenis peraturan yang disebut dalam Pasal 8 ayat (1) tepat disebut sebagai peraturan perundangundangan, melainkan masih dapat dikelompokkan dalam beberapa kategori yaitu, Pertama, peraturan lembaga yang mempunyai daya ikat hanya internal saja, yaitu hanya mengikat organisasi pembuat peraturan karena berkaitan dengan peraturan tata tertib lembaga, susunan organisasi dan sejenis. Masuk kategori ini diantaranya adalah Peraturan MPR, Peraturan DPR, Peraturan DPD, Peraturan Komisi Yudisial.

Kedua, Peraturan lembaga yang pada prinsipnya sebenarnya mengikat internal, namun dalam pelaksanaannya banyak berhubungan dengan subjek-subjek lain di luar organisasi yang akan terkait bila hendak melakukan perbuatan hukum tertentu yang berkaitan dengan lembaga tersebut, diantaranya Peraturan MA dan Peraturan MK, terutama untuk berbagai peraturan mengenai pedoman beracara. Ketiga, Peraturan lembaga yang masuk kategori peraturan perundang-undangan karena mempunyai kekuatan mengikat umum yang lebih luas, misalnya Peraturan Bank Indonesia.

Atas berbagai permasalahan terkait jenis peraturan perundang-undangan dalam UU 12/2011 maka perlu dilakukan usaha penyempurnaan yaitu mengeluarkan beberapa jenis peraturan lembaga/badan yang sebenarnya tidak berkategori sebagai peraturan perundang-undangan melainkan berkategori sebagai peraturan intenal yang mengikat ke dalam dari jenis peraturan perundang-undangan sebagaimana diatur 
Pasal 8 ayat (1). Beberapa peraturan lembaga yang harus dikeluarkan diantaranya adalah peraturan MPR, peraturan DPR, peraturan DPD, peraturan MA, peraturan MK, Peraturan Komisi Yudisial dan Peraturan BPK.

\section{Hierarki Peraturan Perundang- undangan}

Hierarki peraturan perundangundangan memiliki arti penting mengingat hukum adalah sah jika hukum tersebut dibentuk atau disusun oleh lembaga atau pejabat yang berwenang dengan berdasarkan norma yang lebih tinggi. Norma yang lebih rendah tidak akan bertentangan dengan norma yang lebih tinggi sehingga tercipta suatu kaedah hukum yang berjenjang atau hierarki(Soeprapto, 2007).

Pentingnya hierarki dalam sistem perundang-undangan sesuai dengan teori mengenai jenjang norma hukum (Stufenbautheorie). Menurut Hans Kelsen Norma-norma hukum itu berjenjang-jenjang dan berlapis-lapis dalam suatu hierarki (tata susunan), dalam arti, suatu norma yang lebih rendah berlaku, bersumber dan berdasar pada norma yang lebih tinggi lagi, norma yang lebih tinggi berlaku, bersumber dan berdasar pada norma yang lebih tinggi, demikian seterusnya sampai pada suatu norma yang tidak dapat ditelusuri lebih lanjut dan bersifat hipotetis dan fiktif yaitu Norma Dasar (Kelsen, 1973).

Keharusan setiap peraturan perundangundangan jelas letak kedudukannya dalam hierarki peraturan perundang-undangan adalah dalam rangka kemudahan pengujian atas keabsahan (validitas) nya. Dalam konsep negara hukum demokratik, setiap pembentukan peraturan-peraturan negara, baik di tingkat pusat maupun daerah harus dapat dipertanggungjawabkan keabsahannya kepada rakyat. Menurut Widodo Ekatjahjana Rakyat yang menjadi sasaran berlakunya suatu peraturan perundang-undangan memiliki hak untuk mengontrol materi hukum (peraturan perundang-undangan) yang dibuat oleh badan-badan berwenang (Ekatjahjana, 2008).

Dalam hal secara materiil ditemukan adanya materi muatan peraturan perundangundangan yang bertentangan dengan peraturan perundang-undangan yang lebih tinggi, rakyat berhak menggugat atau mengajukan keberatan atas keabsahan berlakunya peraturan perundang-undangan tersebut kepada badan-badan yang berwenang. Badan-badan tersebut selanjutnya melakukan pengujian atas keabsahan (validitas) peraturan perundangundangan itu(Ekatjahjana, 2008).

Saat ini tata urutan peraturan perundang-undangan diatur dalam Pasal 7 ayat (1) UU 12/2011 yang menyebutkan hierarki peraturan perundang-undangan terdiri atas: a. Undang-Undang Dasar Negara Republik Indonesia Tahun 1945; b. Ketetapan Majelis Permusyawaratan Rakyat; c. Undang-Undang/Peraturan Pemerintah Pengganti Undang-Undang; d. Peraturan Pemerintah; e. Peraturan Presiden; f. Peraturan Daerah Provinsi; dan g. Peraturan Daerah Kabupaten/Kota. Atas ini masih menimbulkan permasalahan, diantaranya adalah. Pertama, belum semua peraturan yang dikategorikan sebagai peraturan perundangundang jelas penempatannya dalam hierarki peraturan perundang-undangan sehingga menyulitkan dalam pelaksanaannya dan pengujiannya di badan peradilan. Sebagai contoh dimanakah letak Peraturan Bank Indonesia, peraturan badan, peraturan lembaga, atau Peraturan komisi yang setingkat yang dibentuk dengan UndangUndang atau Pemerintah atas perintah Undang-Undang, yang oleh Pasal 8 ayat (1) UU 12/2011 dikategorikan sebagai peraturan perundang-undangan.

Kedua, terdapat pandangan yang menyatakan bahwa jenis peraturan perundang-undangan seperti Peraturan Bank Indonesia, peraturan badan, peraturan lembaga, atau Peraturan komisi kedudukannya dalam tata urutan sejajar dengan Peraturan Pemerintah karena samasama menjalankan UU. Namun terdapat juga pandangan bahwa peraturan-peraturan tersebut benar ada di bawah Undang-Undang, tetapi tidak dapat dikatakan sejajar dengan Peraturan Pemerintah mengingat Pasal 5 ayat (2) UUD 1945 jelas menyebutkan peraturan yang secara langsung berada di bawah UU hanyalah peraturan pemerintah yang dibentuk oleh pemerintah dengan Presiden sebagai kepala pemerintahan. 
Tidak ditentukannya secara jelas kedudukan tiap jenis peraturan perundangundangan dalam hierarki peraturan perundang-undangan jelas bertentangan dengan pemahaman teoritik bahwa suatu norma hukum itu ke atas ia bersumber dan berdasar pada norma yang diatasnya, tetapi ke bawah ia menjadi dasar dan menjadi sumber bagi norma hukum di bawahnya. Sehingga suatu norma hukum itu mempunyai masa berlaku (rechtskracht) yang relatif oleh karena masa berlakunya suatu norma hukum itu tergantung pada norma hukum yang berada di atasnya. Apabila norma hukum yang berada di atasnya dicabut atau dihapus, maka norma-norma hukum yang berada di bawahnya tercabut atau terhapus pula.

Atas berbagai permasalahan yang ada terkait hierarki peraturan perundangundangan ini maka perlu dilakukan upaya meletakkan setiap jenis peraturan perundangundangan dalam hierarki. Cara yang dapat dilakukan adalah dengan mengelompoklompokkan berbagai jenis peraturan perundang-undangan dalam kelompokkelompok norma hukum. Kelompokkelompok norma hukum tersebut hampir selalu ada dalam tata susunan norma hukum setiap negara walaupun mempunyai istilah yang berbeda-beda ataupun jumlah norma hukum yang berbeda dalam tiap kelompoknya.

Hans Nawiasky mengelompokkan norma-norma hukum dalam suatu negara itu menjadi 4 kelompok besar yang terdiri atas: Kelompok I : staatsfundamentalnorm (norma fundamental negara); Kelompok II: staatsgrundgezets (aturan dasar/pokok negara); Kelompok III: formaile gezets (undang-undang "formal"); Kelompok IV: verordnung \& autonome satzung (aturan pelaksana dan aturan otonom) (Vlies, 2005). Pengelompokkan norma-norma hukum menurut Hans Nawiasky di atas apabila diterapkan dan diterjemahkan dalam konteks Indonesia didapati pengelompokkan sebagai berikut: staatsfundamentalnorm (Pancasila); staatsgrundgezets (aturan dasar negara); formaile gezets (undang-undang (formal)); verordnung \& autonome satzung (peraturan pelaksanaan dan peraturan otonom).

Mendasarkan kepada pengelompokan norma-norma hukum tersebut, maka seluruh jenis peraturan perundang-undangan pada dasarnya dapat masuk dalam hierarki. Untuk itu seharusnya hierarki peraturan perundangundangan di Indonesia terdiri atas: (i) Undang-Undang Dasar; (ii) Ketetapan MPR; (iii) Undang-Undang/Peraturan Pemerintah Pengganti Undang-Undang; (iv) UndangUndang/Peraturan Pemerintah Pengganti Undang-Undang; (v) Peraturan Pemerintah; (vi) Peraturan Presiden/peraturan lembaga negara yang dibentuk berdasarkan ketentuan Undang-Undang Dasar Negara Republik Indonesia Tahun 1945 atau dibentuk berdasarkan ketentuan undang-undang; (vii) Peraturan Menteri; (viii) Peraturan Daerah Provinsi; (ix) Peraturan Kepala Daerah Provinsi; (x) Peraturan Daerah Kabupaten/Kota; (xi) Peraturan Kepala Daerah Kabupaten/Kota; dan (xi) Peraturan Desa.

\section{Materi Muatan Peraturan Perundang- undangan}

Pembentukan peraturan perundangundangan harus benar-benar memperhatikan materi muatan dikarenakan beberapa sebab, pertama, sebagai konsekuensi adanya tata urutan (hierarki) peraturan perundangundangan sehingga setiap jenis peraturan perundang-undangan hanya dapat memuat materi sesuai dengan tingkatan jenis peraturan perundang-undangan. Kedua, dalam membentuk peraturan perundangundangan yang baik harus diperhatikan mengenai materi muatan yang akan dituangkan dalam peraturan perundangundangan tersebut, setiap jenis peraturan perundang- undangan mempunyai materi muatan tersendiri yang biasanya didasarkan pada peraturan perundang-undangan di atasnya (Thaib, 2009). Ketiga, peraturan perundang-undangan itu tersusun secara hierarkis dan mempunyai proporsi materi muatan tertentu(MD, 2010).

Setiap jenis peraturan perundangundangan itu pasti mengatur suatu materi atau hal keadaan/ konkret. Materi apa dan mana yang diatur oleh suatu peraturan itu telah ada ketentuannya. Suatu materi yang menurut ketentuannya harus diatur dengan UU itu tidak dapat dan tidak dibenarkan diatur dengan jenis atau bentuk peraturan lain, misalnya dengan Peraturan Pemerintah atau 
Keputusan Presiden, begitu juga sebaliknya (Soehino, 2006)

Mengenai materi muatan peraturan perundang-undangan, UU 12/2011 mengaturnya dalam beberapa ketentuan yaitu Pasal 10 menyebutkan materi muatan yang harus diatur dengan UU berisi: a. pengaturan lebih lanjut mengenai ketentuan UndangUndang Dasar Negara Republik Indonesia Tahun 1945 ; b. perintah suatu UndangUndang untuk diatur dengan UndangUndang; c. pengesahan perjanjian internasional tertentu; d. tindak lanjut atas putusan Mahkamah Konstitusi; dan/atau; e. pemenuhan kebutuhan hukum dalam masyarakat. Pasal 12 yang menyebutkan Materi muatan Peraturan Pemerintah berisi materi untuk menjalankan Undang-Undang sebagaimana mestinya.

Pasal 13 yang menyebutkan materi muatan Peraturan Presiden berisi materi yang diperintahkan oleh UU, materi untuk melaksanakan Peraturan Pemerintah, atau materi untuk melaksanakan penyelenggaraan kekuasaan pemerintahan. Pasal 14 yang menyebutkan Materi muatan Peraturan Daerah Provinsi dan Peraturan Daerah Kabupaten/Kota berisi materi muatan dalam rangka penyelenggaraan otonomi daerah dan tugas pembantuan serta menampung kondisi khusus daerah dan/atau penjabaran lebih lanjut peraturan perundang- undangan yang lebih tinggi.

Terhadap pengaturan materi muatan dalam UU 12/2011 Terdapat permasalahan sebagai berikut pertama, meskipun hanya memuat lima butir materi muatan UU namun pengaturan dalam Pasal 10 ayat (1) ini menjadi sangat luas dan tidak terbatas dengan adanya butir di huruf e yaitu pemenuhan kebutuhan hukum dalam masyarakat. Ketentuan pemenuhan kebutuhan hukum dalam masyarakat ini terlalu luas mengingat bisa selalu dipakai tanpa ukuran yang jelas. Kriteria pemenuhan kebutuhan hukum dalam masyarakat ini juga kerap menjadi pilihan bagi pembentuk UU untuk mengakomodir kepentingannya dalam pembentukan UU, karena kriteria ini seakan mudah untuk dibuktikan, tanpa harus merujuk kepada peraturan perundang-undangan manapun.

Pengaturan pemenuhan kebutuhan hukum dalam masyarakat sebagai materi muatan yang harus diatur dengan UU ini telah membuka penafsiran yang luas bahwa semua hal dapat diatur dengan UU, akibatnya program pembentukan UU rawan tidak terkontrol dan terukur. Sebagai contoh adalah pembentukan Undang-Undang Nomor 18 Tahun 2014 tentang Kesehatan Jiwa, yang seharusnya perihal kesehatan jiwa cukup diatur dengan Peraturan Pemerintah.

Pasal 151 Undang-Undang Nomor 36 Tahun 2009 tentang Kesehatan sebenarnya telah sangat jelas mengatur dan memberikan delegasi bahwa pengaturan lebih lanjut mengenai upaya kesehatan jiwa diatur dengan Peraturan Pemerintah. Perintah pengaturan dengan Peraturan Pemerintah ini dikarenakan UU 36/2009 Bab IX Pasal 144 sampai dengan Pasal 155 telah mengatur pokok-pokok perihal kesehatan jiwa. Penyebab kesehatan jiwa yang awalnya didelegasikan untuk dibentuk dengan PP menjadi dibentuk dengan UU oleh DPR dikarenakan alasan pemenuhan kebutuhan hukum dalam masyarakat karena adanya desakan kelompok masyarakat.

Kedua, ketidakjelasan mengenai pembedaan materi muatan PP dengan materi muatan Perpres utamanya sama-sama berisi materi yang diperintahkan oleh UU. Hal ini menyulitkan dalam prakteknya utamanya saat pembentuk UU akan memberikan delegasi pengaturan lebih lanjut UU. Seharusnya materi muatan PP dan Perpres dapat dipisahkan secara tegas mengingat kedudukan PP dan Perpres adalah berbeda. PP merupakan kategori verordnung (peraturan delegasi/pelaksana) sementara Perpres merupakan kategori autonome satzung (peraturan Otonom).

Peraturan delegasi/pelaksana adalah peraturan perundang-undangan di bawah UU yang dibentuk sebagai akibat adanya pelimpahan kewenangan membentuk peraturan yang dilakukan oleh peraturan perundang-undangan yang lebih tinggi kepada peraturan perundang-undangan yang lebih rendah (bersumber dari kewenangan delegasi). Peraturan Otonom adalah peraturan perundang-undangan di bawah UU yang dibentuk atas dasar pemberian kewenangan membentuk peraturan oleh grondwet (UUD) atau oleh wet (Undang-Undang) kepada suatu lembaga negara atau lembaga pemerintahan baik di tingkat pusat atau daerah (bersumber 
dari kewenangan atribusi).

Atas berbagai permasalahan yang ada terkait materi muatan peraturan perundangundangan dalam UU 12/2011 maka perlu dilakukan usaha penyempurnaan yaitu pertama, pengaturan mengenai butir-butir materi muatan UU dalam Pasal 10 ayat (1) UU 12/2011 perlu disempurnakan oleh Pembentuk UU dengan mendasarkan pada 12 butir materi muatan UU menurut para ahli dan kesamaan petunjuk materi UU yang diatur dalam konstitusi yang sedang dan pernah berlaku di Indonesia. 12 butir materi muatan UU Indonesia adalah : (i) tegas-tegas diperintahkan oleh UUD; (ii) tegas-tegas diperintahkan oleh Ketetapan MPR; (iii) dinyatakan oleh suatu Undang-Undang untuk diatur dengan Undang-Undang; (iv) mengatur hak-hak (asasi) manusia; (v) mengatur hak dan kewajiban warga Negara; (vi) mengatur lebih lanjut ketentuan UUD; (vii) mengatur pembagian kekuasaan negara; (viii) mengatur organisasi pokok lembagalembaga tertinggi/tinggi Negara; (ix) mengatur pembagian wilayah/daerah negara; (x) mengatur siapa warga negara dan cara memperoleh/kehilangan kewarganegaraan; (xi) pengaturan yang dapat membebani harta kekayaan warga negara; dan (xii) pengaturan mengenai pengeluaran-pengeluaran oleh penyelenggara negara/Keuangan Negara (Anggono, 2014)

Kedua, penegasan kedudukan Perpres sebagai Autonome Satzung (peraturan Otonom). Oleh karenanya Pasal 13 UU 12/2011 perlu diubah dengan hanya menyebutkan materi muatan Perpres berisi materi untuk melaksanakan penyelenggaraan kekuasaan pemerintahan.

\section{Simpulan}

Sistem perundang-undangan Indonesia yang di dalamnya ada unsur jenis, hierarki, dan materi muatan dalam kenyataannya masih mengandung sejumlah permasalahan diantaranya peraturan internal lembaga yang masuk dalam jenis peraturan perundang-undangan, tidak semua jenis peraturan perundang-undangan jelas letaknya dalam hierarki peraturan perundangundangan, dan terlalu luasnya materi muatan serta kesamaan materi muatan antar peraturan perundang-undangan. Untuk itu diperlukan upaya penataan kembali terhadap jenis, hierarki dan materi muatan peraturan perundang-undangan.

Penataan terhadap jenis, hierarki dan materi muatan peraturan perundangundangan dilakukan dengan cara mengeluarkan jenis peraturan yang tidak termasuk peraturan perundang-undangan, memasukkan semua jenis peraturan perundang-undangan dalam hierarki, melakukan pengetatan terhadap suatu materi muatan yang dapat diatur dengan peraturan perundang-undangan, serta melakukan pembedaan secara jelas materi muatan tiap jenis peraturan perundang-undangan.

Penataan ini dapat dilakukan melalui perubahan UU 12/2011. Untuk itu DPR bersama dengan Presiden saat perlu segera untuk merealisasikan rencana perubahan UU $12 / 2011$ agar terwujud tertib perundangundangan di Indonesia sebagaimana menjadi tujuan negara hukum.

\section{DAFTAR PUSTAKA}

Anggono, B. D. (2014). Asas Materi Muatan Yang Tepat Dalam Pembentukan Undang-Undang, Serta Akibat Hukumnya: Analisis Undang-Undang Republik Indonesia Yang Dibentuk Pada Era Reformasi (1999-2012). Jakarta: Universitas Indonesia.

Astawa, I Gde Pantja \& Na,a, S. (2008).

Dinamika Hukum dan Ilmu

Perundang-undangan di Indonesia.

Bandung: Alumni.

Ekatjahjana, W. (2008). Pengujian

Perundang-undangan dan Sistem

Peradilannya di Indonesia. Jakar:

Pustaka Sutra.

Kaufmann, Daniel. Kraay, Aart \& Mastruzzi, M. (n.d.). The Worldwide Governance Indicators Methodology and Analytical Issues, Retrievered. Retrieved January $2, \quad 2018, \quad$ f r o m http://info.worldbank.org/governance/ wgi/pdf/wgi.pdf.

Kelsen, H. (1973). General Theory Of Law and State. Translated By Anders Wedberg. Ney York: Russel\&Russel.

Laporan LeIP. (2018). Retrieved from http://leip.or.id/Latif, A. (2014). Hukum Administrasi Dalam Praktik 
Tindak Pidana Korupsi, Edisi 2. Jakarta: Kencana.

Lubis, M. S. (1977). Landasan dan Teknik Perundang-undangan. Bnadung: Alumni.MD, M. M. (2010). Perdebatan Hukum Tata Negara Pasca Amandemen Konstitusi. Jakarta: Rajawali Press.

Natabaya, H. A. . (2006). Sistem Peraturan Perundang-undangan Indonesia. Jakarta: Sekretariat Jendral Mahkamah Konstitusi.

Ranggawidjaja, R. (1998). Pengantar Ilmu Perundang-undangan Indonesia. Bandung: Mandar Maju.

Soehino. (2006). Hukum Tata Negara, Teknik Perundang-undangan (setelah dilakukan perubahan pertama dan perubahan kedua Undang-Undang Dasar Negara Republik Indonesia Tahun 1945). ed.Pertama. Yogyakarta: BPFE UGM.

Soeprapto, M. F. I. (2007). Ilmu Perundangundangan jilid I, Jenis, Fungsi dan Materi Muatan. Yogyakarta: Kanisius.

Thaib, D. (2009). Ketatanegaraan Indonesia, Perpektif Konstitusional. Yogyakarta: Total Media.Thalib, A. R. (2006). Wewenang Mahkamah Konstitusi \& Implikasinya dalam Sistem Ketatanegaraan RI. Jakarta: Citra Aditya Bakti.

Vlies, I. C. van der. (2005). Buku Perancangan Peraturan Perundangundangan. Terjemahan oleh Linus Doludjawa. Jakarta: Direktur Jenderal Peraturan Perundang-undangan Departemen Hukum dan HAM. 